\title{
Business case for One-stop Transnasal Oesophagoscope Service Adoption
}

Narun Tantichirasakul ${ }^{1}$, Ravneet Grewal ${ }^{1}$, Natalie Watson $^{2}$, Benjamin Miller ${ }^{2}$, and Yakubu Karagama $^{2}$

${ }^{1}$ King's College London GKT School of Medical Education

${ }^{2}$ Guy's and St Thomas' NHS Foundation Trust

May 15, 2021

\begin{abstract}
Keypoints: * Implementing a one-stop Transnasal oesophagoscopy (TNO) service will benefit patients, clinicians as well as the NHS Trusts. * TNO is safe, well-tolerated and improves diagnostic and therapeutic precision in the upper aerodigestive tract and oesophagus. ${ }^{*}$ The one-stop TNO service has clear financial benefits. ${ }^{*}$ The one-stop TNO service is a streamlined pathway which improves patient care and experience. ${ }^{*}$ Both the clinical and financial risk of introducing the service is low.
\end{abstract}

\section{Hosted file}

Main_document (3).pdf available at https://authorea.com/users/413928/articles/522116business-case-for-one-stop-transnasal-oesophagoscope-service-adoption 


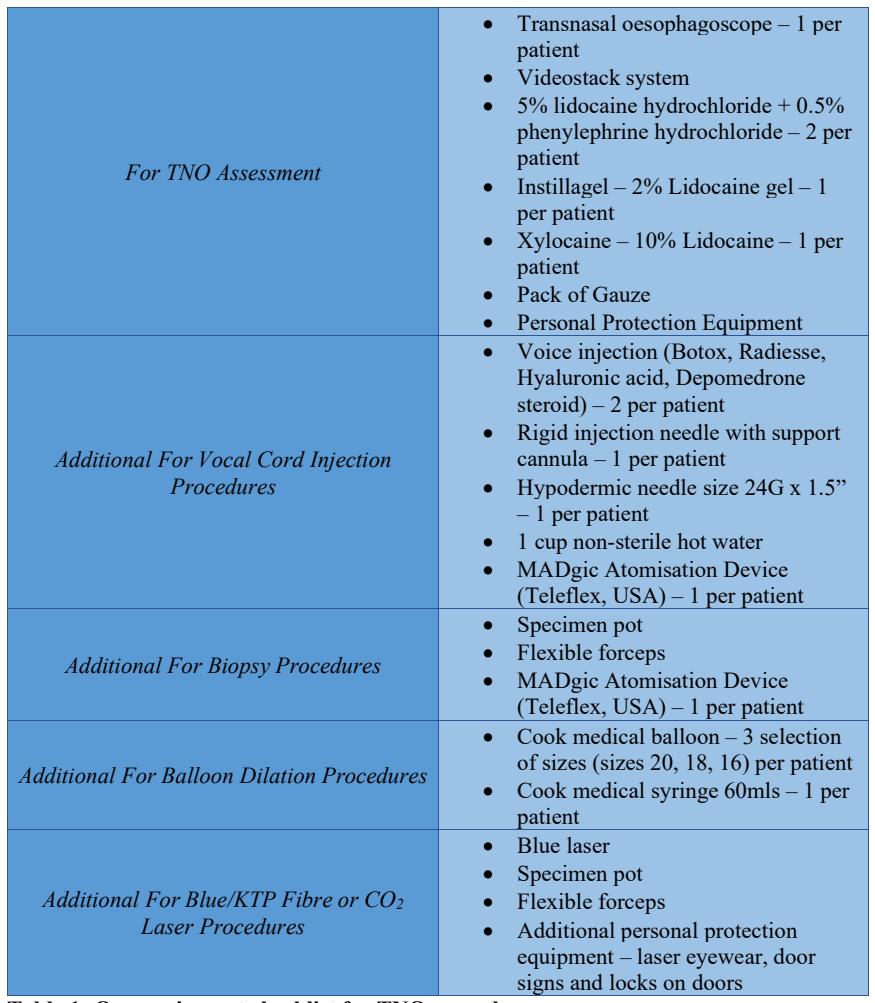

Table 1: Our equipment checklist for TNO procedures 


\begin{tabular}{|l|l|l|}
\multicolumn{1}{|c|}{ Clinicians } & \multicolumn{1}{|c|}{ NHS Trusts } & \multicolumn{1}{c|}{ Patients } \\
\hline $\begin{array}{l}\text { Comprehensive ENT } \\
\text { examination from nasal } \\
\text { cavity } \\
\text { to GOJ }\end{array}$ & $\begin{array}{l}\text { Switch from in-patient } \\
\text { setting to out-patient one- } \\
\text { stop clinic setting thereby } \\
\text { reducing the patients' length } \\
\text { of hospital stay }\end{array}$ & $\begin{array}{l}\text { Reduces the time to } \\
\text { diagnosis and treatment } \\
\text { improving continuity of } \\
\text { patient care and experience }\end{array}$ \\
\hline $\begin{array}{l}\text { Digital High-Resolution } \\
\text { imaging increasing } \\
\text { diagnostic yield and biopsy } \\
\text { precision }\end{array}$ & $\begin{array}{l}\text { Reduces waiting lists in day } \\
\text { surgery, main theatre, } \\
\text { barium swallows and } \\
\text { radiology where these spaces } \\
\text { can be assigned to other uses }\end{array}$ & $\begin{array}{l}\text { Early and more accurate } \\
\text { diagnosis means better } \\
\text { outcomes }\end{array}$ \\
\hline $\begin{array}{l}\text { Eliminates risks associated } \\
\text { with GA, particularly } \\
\text { valuable in high risk patients }\end{array}$ & $\begin{array}{l}\text { Shorter procedure time and } \\
\text { more cost beneficial to the } \\
\text { Trust }\end{array}$ & $\begin{array}{l}\text { Immediate results remove } \\
\text { stress of waiting and the } \\
\text { need for additional travel for } \\
\text { result clinics }\end{array}$ \\
\hline Equipment is user friendly & $\begin{array}{l}\text { Eliminates need for bed } \\
\text { spaces }\end{array}$ & $\begin{array}{l}\text { Out-patient setting less } \\
\text { daunting to patients than } \\
\text { theatre }\end{array}$ \\
\hline $\begin{array}{l}\text { Can be performed in } \\
\text { outpatient setting so there is } \\
\text { no need for theatre } \\
\text { preparations }\end{array}$ & $\begin{array}{l}\text { Saving theatre resources for } \\
\text { other procedures }\end{array}$ & $\begin{array}{l}\text { Avoidance of GA often } \\
\text { means less risks and quicker } \\
\text { recovery }\end{array}$ \\
\hline & $\begin{array}{l}\text { Reduce need for outpatient } \\
\text { results clinic visits due to } \\
\text { instant results }\end{array}$ & $\begin{array}{l}\text { Reduces time spent in the } \\
\text { hospital, minimising risk of } \\
\text { hospital acquired infection }\end{array}$ \\
\hline
\end{tabular}

Table 2: Summary of the key benefits of a one-stop TNO service to clinicians, NHS trusts and patients [3-5] 


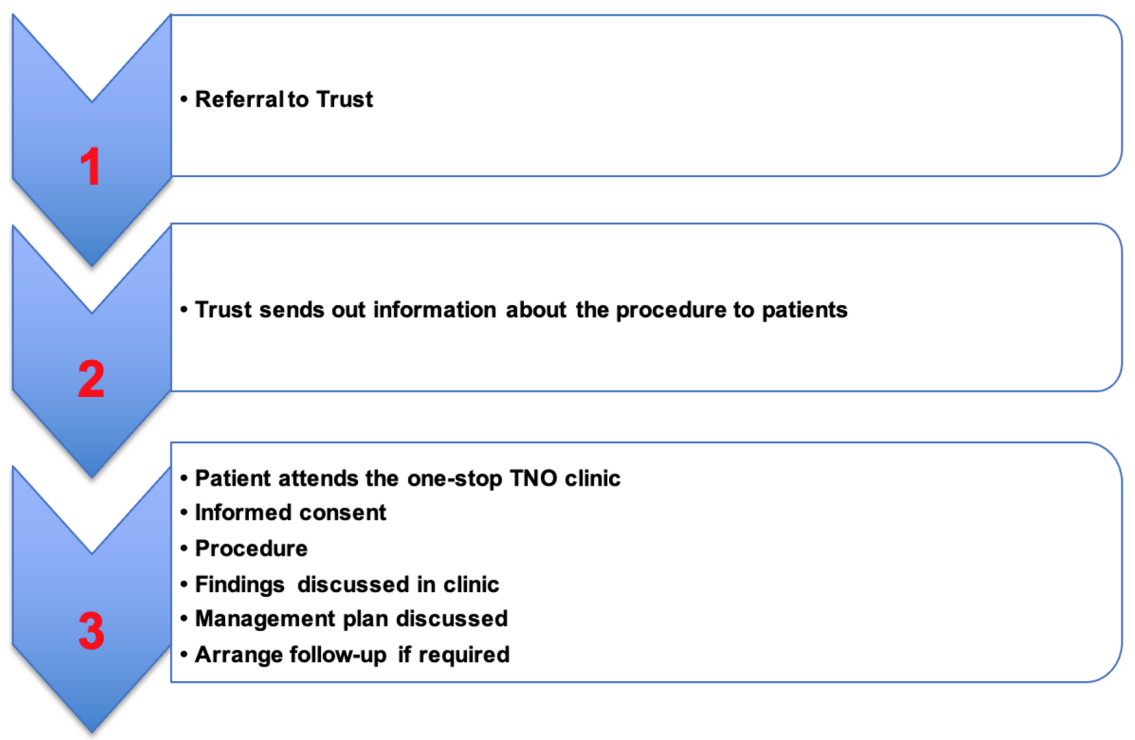

Figure 1: One-stop Transnasal Oesophagoscopy Service Pathway

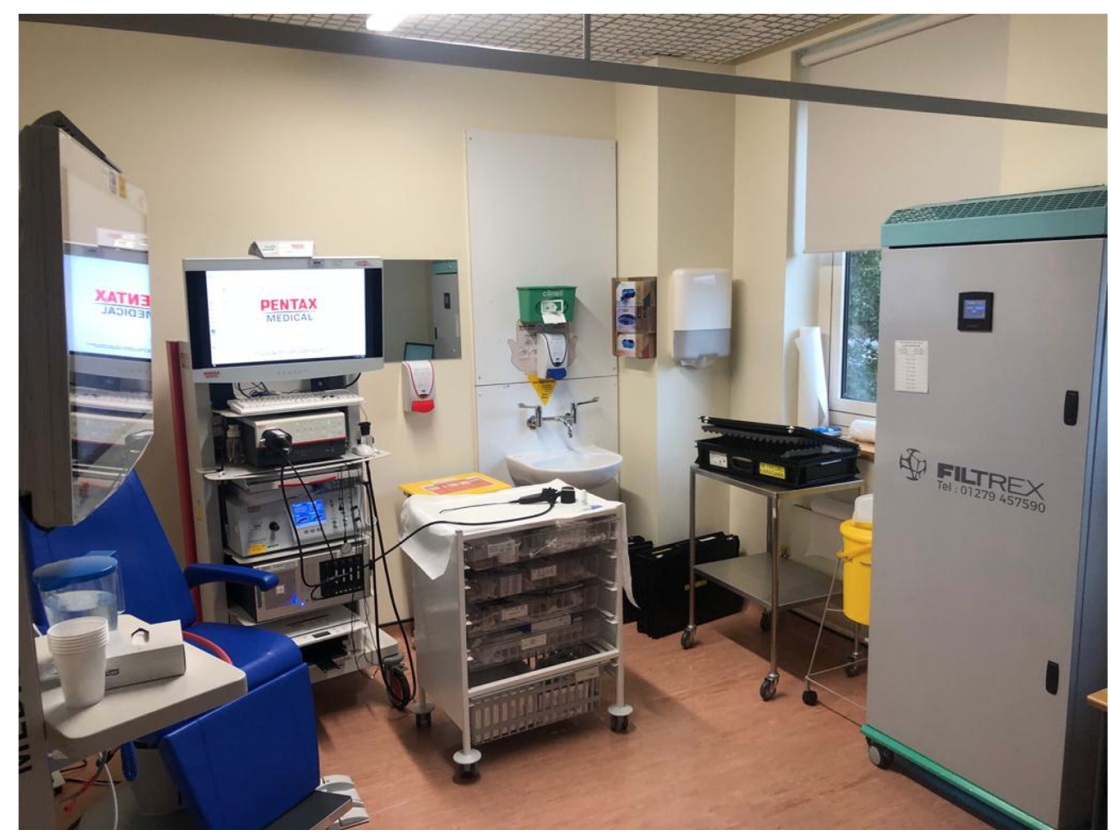

Figure 2: Example of an outpatient set up 